\title{
Comparison and Analysis of Publicly Available Bathymetry Models in the East Adriatic Sea
}

\section{Usporedba i analiza javno dostupnih batimetrijskih modela na području istočnog Jadranskog mora}

\author{
Ljerka Vrdoljak \\ Hydrographic Institute of the Republic of Croatia \\ Hydrographic department \\ E-mail: ljerka.vrdoljak@hhi.hr
}

DOI 10.17818/NM/2021/2.7

UDK 551.462:528.02(262.3)

Review / Pregledni rad

Paper accepted / Rukopis primljen: 22. 9. 2020.

Summary

In this paper the latest versions of six publicly available bathymetry models: DTU10bat, EMODnet 2018, ETOPO1, GEBCO 2020, Smith and Sandwell V20.1 and SRTM15+ V.2.1. are compared and evaluated in the area of continental shelf of Croatia settled along well intended east Adriatic coast. Survey data in the area is not available through open access data bases, but publicly accessible in agreement with data holders (hydrographic institute, research centres and industry). These grids provide alternative sources of information about seafloor topography. Marine researchers should be acquainted with the main characteristics as well as pros and cons of bathymetry models in order to choose the best one for a specific purpose. In this paper the most important characteristics and information about grids are presented: resolution, coverage, release date, horizontal and vertical datum, data source, registration method, producer and link to website with an emphasis on the underlying source data. The underlying source data is one of the most important parameters that determine the quality of the bathymetric model. Hypsometry curve that is describing the area distribution of depth is calculated for each bathymetry model over the test area of the east Adriatic. For pixel to pixel comparison, grids were resampled to same one-minute resolution and absolute differences between models are calculated in identical points. Absolute differences between models show level of mutual compatibility between models as well as areas of highest disagreements that indicate the presence of outliers or systematic errors within models. In order to demonstrate how well publicly available bathymetry models fit the true topography of the sea floor, grids were compared to high-resolution digital bathymetry model interpolated from the multibeam survey in the area of Murter Sea. This paper should assist in the choice of a most suited bathymetry grid in future maritime studies in the Adriatic.

\section{Sažetak}

U ovom radu uspoređuju se i analiziraju najnovije verzije šest javno dostupnih batimetrijskih modela: DTU10bat, EMODnet 2018, ETOPO1, GEBCO 2020, Smith i Sandwell V20.1 te SRTM15+ V.2.1. na području epikontinentalnog pojasa Republike Hrvatske smještenog duž istočne obale Jadranskog mora, specifične po svojoj razvedenosti. Podaci batimetrijskih izmjera nisu dostupni u bazama podataka otvorenog pristupa, već im se može pristupiti u dogovoru s vlasnicima batimetrijskih podataka (hidrografski institut, akademski sektor i privreda). Navedeni su modeli alternativan izvor podataka o topografiji morskog dna. Znanstvenici i ostali korisnici batimetrijskih podataka trebaju poznavati osnovne karakteristike pojedinog modela te njihove prednosti i nedostatke kako bi se izabrao najbolji model za određenu namjenu. $U$ ovom radu izdvajaju se najvažnije karakteristike i podaci o modelima: rezolucija, obuhvat, godina objave, horizontalni $i$ vertikalni datum, izvorni podaci, način registracije, proizvođač i mrežna stranica za pristup podacima, s naglaskom na izvorne batimetrijske podatke na temelju kojih je model izračunat. Izvorni su podaci jedan od najvažnijih parametara koji određuju kvalitetu modela. Hipsometrijska krivulja, koja opisuje razdiobu dubina s obzirom na površinu koju zauzima određena vrijednost, izračunata je za svaki model na testnom području istočnog Jadrana. Apsolutne razlike između modela, u istoj rezoluciji od jedne minute, izračunate su u identičnim točkama. Apsolutne razlike ukazuju na stupanj međusobne podudarnosti modela, kao i na područja najveći razlika koje se javljaju zbog mogućih grubih ili sistematskih pogrešaka u pojedinom batimetrijskom modelu. Podaci javno dostupnih batimetrijskih modela uspoređuju se s podacima izmjere višesnopnim dubinomjerom na području Murterskog mora kako bi se usporedila usklađenost sa stvarnom topografijom morskog dna. Svrha je ovog rada pomoći pri odabiru najprikladnijeg batimetrijskog modela u budućim istraživanjima na području Jadranskog mora.

\section{INTRODUCTION / Uvod}

Bathymetry refers to the information about depth of the sea, i.e. a vertical distance to the seafloor relative to the chosen sea level. Digital bathymetry model (DBM) is a digital terrain model that represents topography of seafloor [32], mostly in

the form of regular grid with depth values assigned to grid cells [28]. Since oceans and seas cover more than $71 \%$ of the Earth [9], knowing topography of the seafloor is important on both global and local scale preferably formatted in the form of 
digital bathymetry model. It is possible to derive seafloor terrain attributes: slope, orientation, curvature, variability directly from digital bathymetry model [31] or to use it as frame in different scientific analyses. Although primary use of bathymetry data is to ensure safety of navigation [27], bathymetry data is a necessary parameter in many studies: geohazard assessment in offshore area [8], reviling marine geomorphology [38], computations in physical geodesy [44], tsunami modelling [30], modelling atmospheric influence in offshore area and effect of meteotsunami $[39,45]$, modelling ocean currents [15], mapping marine habitats $[7,49]$, etc.

Despite the fact that bathymetry data underpins almost all maritime activities, accessing directly observed bathymetry data is not an easy task for several reasons.

Even though collecting bathymetry data lasts for centuries, less than $20 \%$ of ocean floor at 30 arc seconds resolution has been directly surveyed by echo sunders $[34,48]$. It is commonly said that some planets in solar system are better mapped than oceans. It is predicted that seafloor mapping below $200 \mathrm{~m}$ with one ship would last 350 years with a total cost of 3 billion US \$. It equals in cost to ne extra-terrestrial mission [19, 34].

As compared to deep ocean areas, coastal continental shelf, defined as sea area limited to a distance of 200 nautical miles from the baseline of a coastal state [42], are very well surveyed but these data are held private by governments, research institutions or private companies [50].

Alternative bathymetry data sources are publicly available bathymetry grids. Publicly available bathymetry grids can be global or regional. They are calculated using different type of source data: shipboard soundings, nautical chart soundings and contours, satellite derived bathymetry using multispectral images, bathymetry data predicted from gravity, etc. Data is collected in different time periods using diverse technology and interpolation methods. As a result, there is a number of publicly available grids to choose from today. To know which grid to choose for a specific purpose, grids should be compared and analysed. As terrestrial global digital terrain models are regularly evaluated on global and regional levels, such studies are rarely done for publicly available bathymetry grids.

Marks and Smith in 2006 evaluated six global publicly available bathymetry grids with a focus on a Woodlark Basin and adjacent Coral sea area east of Papua New Guinea which is an area that exhibits a variety of sea floor features, including abyssal hills, seamounts, a plateau, ridges, fracture and a subduction zone [33]. Although evaluation was made 14 years ago and observed models are outdated, they have underlined features and characteristics of digital bathymetry model that affect the accuracy: source data, interpolation method, presence of artifacts, etc. Abramova in 2012 followed and broadened the work of Marks and Smith and evaluated grids over specific Artic region [1]. In 2019 Florentino et al. compared global bathymetry models in area near Brazil and demonstrated how grids can be updated with more accurate regional data [11]. Analyses of digital bathymetry models in Adriatic have, to some extent, already been made for the purpose of physical geodesy. Bašić and Buble in 2007 evaluated Smith and Sandwell model, incorporated in ETOPO 2 and SRTM30+ models, against contour data derived from nautical map over the Adriatic Sea (scale 1 :1 000 000) [4]. In the same area, Bjelotomić in 2015 mutually compared six bathymetry grids: International Gravimetric
Bureau model BGI, DTU10bat, GEBCO, ETOPO, Morelli, SRTM30+, Smith and Sandwell in order to compute regional geoid [5].

The purpose of this study is to analyse and compare latest versions of publicly available bathymetry models in shallow sea area of the east Adriatic Sea. Unlike the west Adriatic coast that is generally regular, sandy and with a gentle slope, east coast is challenging to model because it is irregular, with many islands, and a rocky steeply sloping bathymetry [35]. Six publicly available bathymetry models: DTU10bat, ETOPO1, EMODnet, GEBCO, SRTM15+, Smith and Sandwell are compared and analysed in the continental shelf of the Republic of Croatia settled in east Adriatic Sea (Figure 1a). This work provides mutual comparison between latest versions of grids available at the moment and analyses of underlying source data, general statistics and distribution of depth. Furthermore, digital bathymetry grids are compared with high resolution digital bathymetry model $(2 \mathrm{~m}$ grid spacing) based on multibeam data in the area of Murter Sea which is an example how data fit actually terrain (Figure 1b). This analysis should assist in choice of a most suited bathymetry grid in future maritime studies.

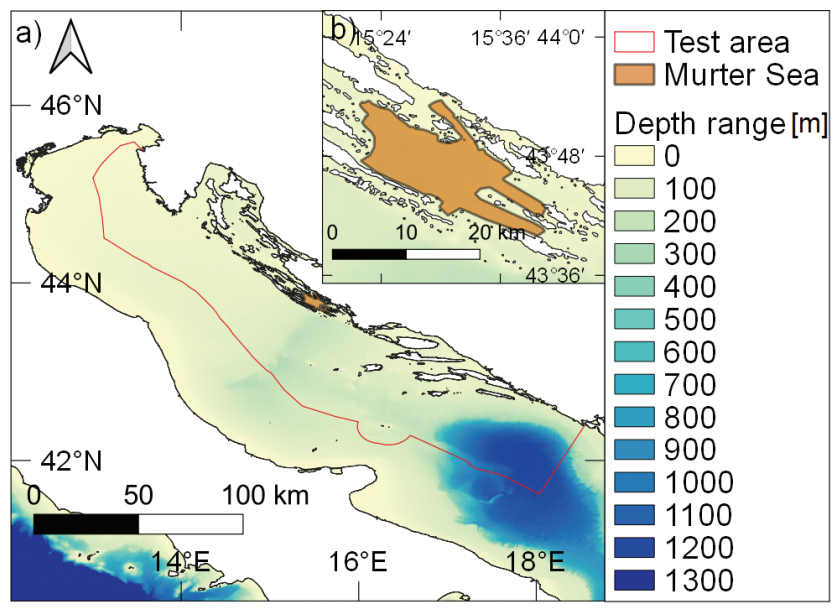

Figure 1a Continental shelf of the Republic of Croatia bounded with red line. Bathymetry is derived from GEBCO 2020 grid. Test area is on one side defined by border of continental shelf defined by maritime law and encompasses all of grid cells with value $<0 \mathrm{~m}$ in their original format. Slika $1 \mathrm{~b}$. Područje izmjere višesnopnim dubinomjerom u Murterskome moru.

Slika 1a. Obuhvat epikontinentalnog pojasa Republike Hrvatske označen je crvenom linijom. Batimetrijski podaci preuzeti su iz GEBCO 2020 modela. Testno je područje definirano granicom epikontinentalnog pojasa (granica određena međunarodnim pomorskim pravom) s vanjske strane i obuhvaća sve ćelije modela $s$ vrijednošću $<0$ m u izvornom formatu. Figure 1b. Area of Murter Sea covered with multibeam survey.

\section{DATA AND METHODS / Podaci i metode}

In this study six publicly available digital models are tested in the Croatian continental shelf. Following section gives a description of bathymetry grids with an emphasis on underlying source data and methods used to mutually compare them.

\subsection{Bathymetry models and source data / Batimetrijski modeli i izvor podataka}

Basic characteristics of six publicly available grids that are examined are summarised in Table 1. The resolution of digital bathymetry model refers to spatial sampling interval, simply to the size of its grid cell. However, spatial resolution of a sensor, 
Table 1 Basic characteristics of bathymetry grids $[2,3,10,12,14,41]$

Tablica 1. Osnovne značajke batimetrijskih modela $[2,3,10,12,14,41]$

\begin{tabular}{|c|c|c|c|c|c|c|}
\hline DBM & DTU10BAT & EMODnet & ETOPO & GEBCO & SRTM15+ & SS \\
\hline Resolution & 1 arc minute & $1 / 16$ arc minute & 1 arc minute & 15 arc seconds & 15 arc seconds & 1 arc minute \\
\hline Resolution for $\mathrm{f}=45^{\circ}[\mathrm{m}]$ & 1300 & 90 & 1300 & 330 & 330 & 1300 \\
\hline Coverage $\left(^{\circ}\right)$ & Global & $\begin{array}{l}15 \mathrm{~N}-90 \mathrm{~N} \\
36 \mathrm{~W}-43 \mathrm{E}\end{array}$ & Global & Global & Global & Global \\
\hline Tested version & DTU10 & EMODnet 2018 & ETOPO 1 & GEBCO 2020 & SRTM15+V2.1 & SS V20.1 \\
\hline $\begin{array}{l}\text { Release Date: } \\
1^{\text {st }} \text { version } \\
\text { Tested version }\end{array}$ & $\begin{array}{l}2008 \\
2010\end{array}$ & $\begin{array}{l}2013 \\
2018\end{array}$ & $\begin{array}{l}1998 \\
2008\end{array}$ & $\begin{array}{l}1994 \\
2020\end{array}$ & $\begin{array}{l}2008 \\
2020\end{array}$ & $\begin{array}{l}1996 \\
2020\end{array}$ \\
\hline $\begin{array}{l}\text { Horizontal, Vertical } \\
\text { datum }\end{array}$ & $\begin{array}{l}\text { WGS84, } \\
\text { MSL }\end{array}$ & $\begin{array}{l}\text { WGS84, } \\
\text { LAT \& MSL }\end{array}$ & $\begin{array}{l}\text { WGS84, } \\
\text { SL }\end{array}$ & $\begin{array}{l}\text { WGS84, } \\
\text { MSL }\end{array}$ & $\begin{array}{l}\text { WGS84, } \\
\text { MSL }\end{array}$ & $\begin{array}{l}\text { WGS84, } \\
\text { MSL }\end{array}$ \\
\hline Data source & $\begin{array}{l}\text { Bathymetry } \\
\text { predicted from } \\
\text { gravity }\end{array}$ & $\begin{array}{l}\text { Soundings with gaps } \\
\text { filled with GEBCO }\end{array}$ & $\begin{array}{l}\text { Global and } \\
\text { regional } \\
\text { bathymetry } \\
\text { grids }\end{array}$ & $\begin{array}{c}\text { Base layer } \\
\text { SRTM15+V.2 is } \\
\text { augmented with } \\
\text { heterogeneous data }\end{array}$ & $\begin{array}{l}\text { Bathymetry } \\
\text { predicted from } \\
\text { gravity }\end{array}$ & $\begin{array}{l}\text { Bathymetry } \\
\text { predicted } \\
\text { from gravity }\end{array}$ \\
\hline Registration & Grid & Pixel & Grid/Pixel & Pixel & Pixel & Pixel \\
\hline Generation & DTU Space & $\begin{array}{c}\text { EMODNet } \\
\text { Compilation Group }\end{array}$ & NGDC & Seabed 2030 Project & $\begin{array}{l}\text { NGA, JAMSTEC, } \\
\text { GA, CCOM, SIO }\end{array}$ & $\mathrm{SIO}$ \\
\hline Website & [24] & [18] & [23] & [17] & [21] & [12] \\
\hline
\end{tabular}

* SS Smith and Sandwell, MSL Mean Sea Level, LAT Lowest Astronomical Tide, SL Sea Level, DTU Technical University of Denmark, NGDC American National Geophysical Data Center, NGA National Geospatial-Intelligence Agency (USA), JAMSTEC Japan Agency for Marine-Earth Science and Technology, GA Geoscience Australia, CCOM Center for Coastal and Ocean Mapping (USA), SIO Scripps Institution of Oceanography (USA)

measure of smallest object that can be resolved by sensor can be by far greater [41] or the depth of a particular cell may be interpolated from a relatively distant source data since only a small part of worlds sea areas is measured [34, 41], so this can be a misleading value. Thus, it is important to know the source of data upon which cell depth is derived and the information about it should be available for all grid cells.

Information about source data that grids are built upon is given below, starting with DTU10BAT model, in alphabetical order.

DTU10 Bathymetry (DTU10BAT) is a Danish global bathymetry model developed at the Danish National Space Institute (DTU Space) [3]. The model is calculated from global gravity model DTU10 and depths from GEBCO One Minute Grid [6] (Figure 2a) using the Smith and Sandwell method to predict depths from gravity [37] with one arc minute grid spacing. In contrast to the first version of the model DNSC08, released in 2008, DTU10 included data from ERS1 and GEOSAT altimetry missions which enhanced recovering of even small seamounts.

EMODnet 2018 bathymetry grid (EMODnet) is a regional bathymetry model that is covering the area of European seas with $1 / 16$ arc minute resolution [10]. It is part of European Marine Observation and Data Network, developed under EU Marine Strategy Framework Directive and the EU Marine Knowledge 2020 agenda and financed by the European Union. Data collection started in 2009 and the first version of the model with 15 arc seconds resolution was released in 2013 [40]. It is constructed from heterogenous bathymetry data sets including survey data, data from nautical chats and composite grids with gaps filled with GEBCO 2014 grid. EMODnet bathymetry portal provides source data reference for every cell through metadata with quality indicators and link to data source holder. In test area, part of Kvarner bay and coastal sea area near Dubrovnik are based on ENC (Electronic navigation chart) data with following quality indicators: Vertical (VI): 1 (multisource), Horizontal (HI): 1 (multisource), Usage (UI): 3 (hydrographic survey or compatible with hydrographic standards), part of eastern slope of South Adriatic basin is covered with multibeam data VI: MBES low frequency, HI: $3(<20 \mathrm{~m}), \mathrm{UI}: 2$ (bathymetric/ morphologic survey) and border of test area is interpolated from singlebeam soundings Vl:1 (similar than 2+5\%d), $\mathrm{HI}: 3$ (< 20m), UI: 2 (bathymetric/morphologic survey). However, most of area is filled with GEBCO 2014 data (Figure 2b).

ETOPO 1 is a global terrain model for land and sea areas, generated and published by the American National Geophysical Data Center (NGDC) in 2008 [2]. It is constructed by patching several available regional and global bathymetry models. Bathymetry data is mainly based on GEBCO and Smith and Sandwell (SS) models. ETOPO1 is publicly available in two versions: "Ice Surface" version that includes the Antarctic and Greenland ice sheets, and a "Bedrock" version that delineates the bedrock underneath the two ice sheets. ETOPO 1 only indicates source data for test area to be GEBCO and SS model.

GEBCO 2020 grid is a continuous, global topography and bathymetry model with spatial resolution of 15 arc seconds [14]. It is produced through the Nippon Foundation - General Bathymetric Chart of the Oceans (GEBCO) Seabed 2030 Project. Base of the model is SRTM15+ data which is augmented with bathymetry data, mainly based on multibeam surveys, collected through Seabed 2030 project. Compared to the earlier version of the model GEBCO 2019 where new data was added to the model using remove-restore procedure [13], new data is added to the base layer of GEBCO 2020 "as it is", without any blending to avoid the edge effect on boundaries between layers. GEBCO 2020 bathymetry grid is accompanied by Type Identifier Grid (TID). This data set identifies the type of source data that the corresponding grid cells in the GEBCO grid are based on. As seen in Figure 2c, in test area, data is mainly based on gravity predicted data (SRTM 15+) augmented with soundings from combination of direct measurements methods and different chart data, not referring to the data holder. However, since GEBCO and EMODnet are exchanging data, it is noticeable that different direct measurements in GEBCO TID grid originate from EMODnet database.

SRTM15+V2.1 is a global terrain model for ocean and land with spatial sampling interval of 15 arc seconds [41]. Version 


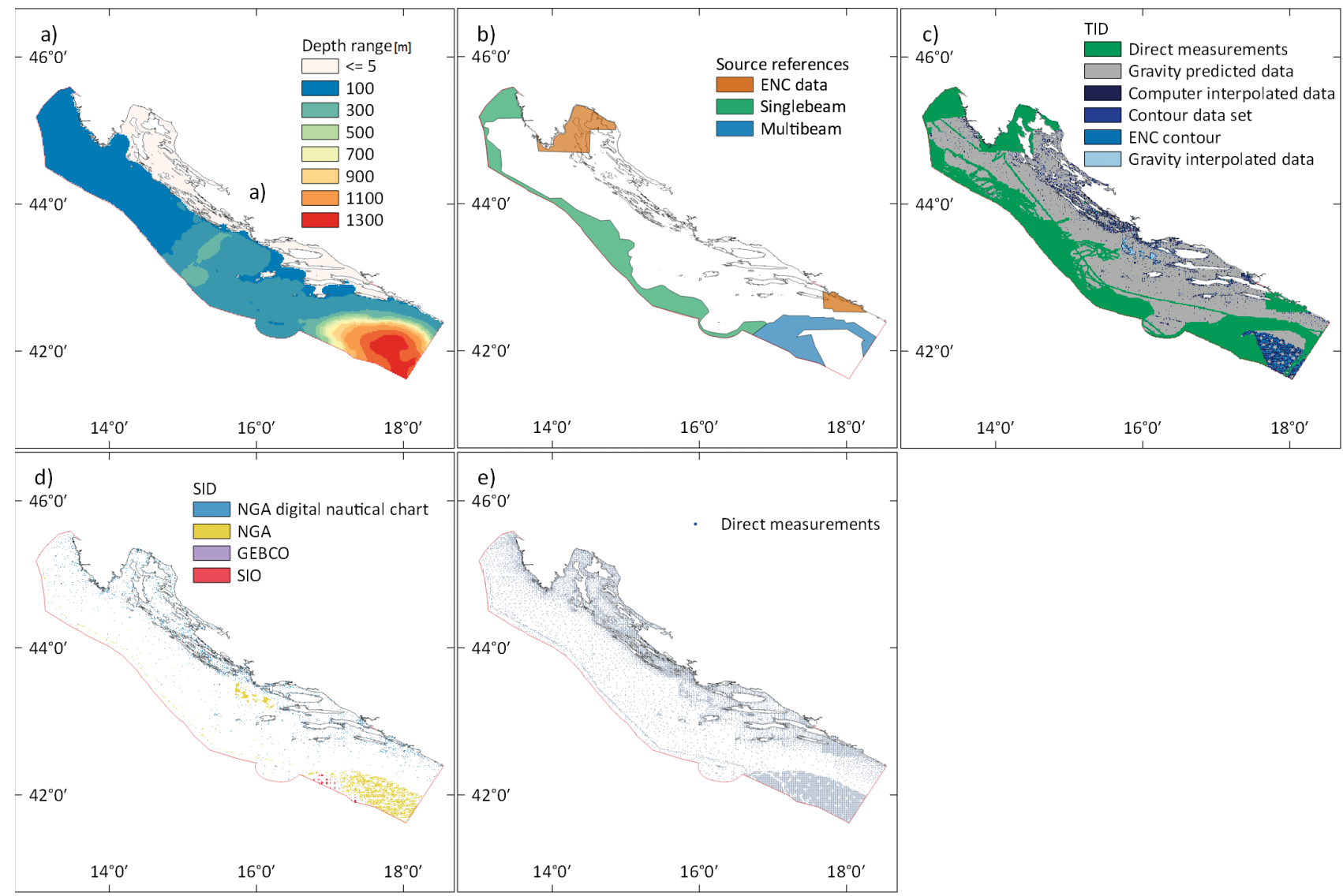

*ENC Electronical navigational chart, NGA National Geospatial-Intelligence Agency (USA), GEBCO General Bathymetric Chart of the Oceans, SIO Scripps Institute of Oceanography

Figure 2 Source data of digital bathymetry models in test area (defined with red line):

a) GEBCO One Minute grid [22], b) Data used in EMODnet model [18], c) Type Identifier Grid (GEBCO 2020) [17], d) Source Identifier Grid (SRTM15+V.21) [21], e) Soundings used in calculation of Smith and Sandwell model [20]

Slika 2. Izvor podataka batimetrijskih modela na testnom području (označeno crvenom linijom): a) GEBCO jednominutni model [22], b) Podaci korišteni u EMODnet modelu [18], c) Identifikator tipa (GEBCO 2020) [17], d) Identifikator posjednika podataka (SRTM15+V.21) [21], e) Izravno mjerene dubine u Smith i Sandwell modelu [20]

V2.1 is year 2020 release of SRTM15+V2 version and follows the preceding versions of SRTM+ model, SRTM30+V.11 and SRTM15+V1, where plus in the name refers to bathymetric addition. Bathymetry is calculated combining gravity derived bathymetry and shipboard soundings collected by National Geospatial-Intelligence Agency (NGA), Japan Agency for Marine-Earth Science and Technology (JAMSTEC), Geoscience Australia (GA), Center for Coastal and Ocean Mapping (CCOM), and Scripps Institution of Oceanography (SIO) in two phases. The first phase is a construction of the1-minute grid using a combination of V29.1 gravity model (SIO) and ship soundings augmented with depths from GEBCO 1-minute grid [6] following Smith and Sandwell method [37]. The second phase increases the resolution of the grid to 15 arc seconds and upgrades base map using remove-restore procedure where ship soundings are available. As compared to previous versions, new version included more years of altimetry measures and new shipboard soundings covering $10.84 \%$ of ocean floor in 15 arc resolution, which results in improvement in the spatial resolution $(\sim 6 \mathrm{~km})$ and accuracy of gravity predicted bathymetry. Source Identifier (SID) Grid supports bathymetry grid and identifies source of data used to calculate the depth within the grid cell (Figure 2d). In the test area the data soundings are obtained from NGA, GEBCO and SIO databases, where SIO data is only publicly available.

Smith and Sandwell bathymetry model (SS) released in
1996 was the first bathymetry model derived from satellite gravity data (track spacing 2-4 km) and sparse in situ soundings (hundreds of kilometres between tracks in some areas) [38]. The model was covering ocean area between $\pm 72^{\circ}$ latitude with uniform 2-minute grid spacing revealing new geological structures and unknown topography of ocean floor with 12.5 $\mathrm{km}$ spatial resolution. The mathematical base of the model is Smith-Sandwell method which defines correlation between marine gravity anomalies and changes in sea floor topography [37]. The model is regularly updated with new altimetry data and shipboard soundings and thus new versions have better resolution and accuracy. Tested version of SS model, V20.1 is released in 2020 with 1-arc minute resolution. It is calculated from Smith and Sandwell V29.1 gravity model [36] and ship sounding from Scripps Institute of Oceanography (SIO) database which is regularly updated with new data. Odd values of topography are constrained by actual soundings while even values are predicted from gravity. Therefore, one can extract the locations of the ship sounding and there are 10519 soundings in the test area (Figure 2e). There is no data about the type or quality of the data but since SS and SRTM+ are based on almost the same source soundings, data owner can be determined from Source Identifier (SID) grid of SRTM15+ model.

Apart from publicly available grids, high resolution digital bathymetry model HRDBM, based on multibeam data in the area 
of Murter sea (Figure 1b) is used for grid comparison. HRDBM is interpolated to a grid with $2 \mathrm{~m}$ resolution from the multibeam survey, done in 2018 following IHO S44 standard [26] with Kongsberg EM2040 multibeam echo sounder operated using Kongsberg's seafloor information system (SIS).

\subsection{Methods / Metode}

In this study digital bathymetry models (DBM) are analysed using QGIS software, Open Source Geographic Information System, version 3.10 A Coruna. DBM are analysed over the area of continental shelf of Croatia. General statistics (mean depth ME, median depth MED, maximum depth MAX, standard deviation STDEV) for all models were calculated at their original resolution and projection using the "Zonal Statistics" tool in QGIS.

Marine geomorphometry is a science of quantitative analyses of seafloor focused on characterization of seabed terrain [31]. Hypsometry is widely used geomorphometric parameter that refers to elevation or depth relative to chosen zero level. Hypsometric curve represents the area distribution of depth over specified area. The tool hypsometry curve in QGIS was used to derive the graph for all publicly available digital bathymetry models at 10-meter depth interval. For this operation all grids were transformed and projected to Lambert azimuthal equal area projection with the parameters specified in the European Terrestrial Reference System (ETRS) 1989 recommended by the EU INSPIRE Directive for statistical analyses of data spanning large parts of Europe when true area representations are required [25]. Projection parameters can be found by the European petroleum survey group (EPSG) code 3035 in most GIS software including QGIS.

In order to mutually compare digital bathymetry models of different resolution, it is necessary to resample them to identical grid size [5, 43]. All models were resampled to 1-minute grid using bilinear interpolation model in their original datum for two reasons: it is more reliable to convert from higher to coarser resolution and secondly, almost all model to some extent rely on data from SS model that has 1-minute resolution. Absolute differences between models are used as statistic in comparison because emphasis is on the magnitude of the differences and not their sign. Apart from the most commonly used statistical measures mean (ME) and standard deviation (STDEV), robust statistical methods median (MED) and Mean absolute deviation (MAD) were calculated (Table 3). Publicly available models use data from different sources with unknown quality and robust statistical methods are more reliable for data which may have systematic and gross errors [16].

Bathymetric profile in the area of Murter sea was generated from high resolution digital bathymetry model HRDBM and compared to profiles between the same points generated from publicly available models using Profile tool plugin in QGIS.

Methods used for analyses and comparison of digital bathymetry models are graphically presented in Figure 3.

\section{RESULTS AND DISCUSSION / Rezultati i diskusija}

Results of mutual comparison of grids as described in flowchart in Figure 3 are presented and analysed in the next section.

\subsection{Basic feature / Osnovne značajke}

General statistics of tested digital bathymetry models are given in Table 2. Average depth of tested digital bathymetry models in continental shelf of Croatia ranges from 207 m (ETOPO) to 226 $\mathrm{m}$ (DTU) and maximum depth ranges from $1181 \mathrm{~m}$ (ETOPO) to $1277 \mathrm{~m}$ (DTU). It is generally accepted that the deepest point of Adriatic is nearly $1240 \mathrm{~m}$ in South Adriatic Pit (SAP) $[29,46,47]$ so differences between these values suggest presence of outliers in models. GEBCO, SRTM15+ and Smith and Sandwell (SS) grids are based on the same source data and their compatibility is visible from almost identical statistic values of grids. As compared to those three grids, DTU, EMODnet and ETOPO have different statistic values that are unique for each grid. It was not expected for EMODnet grid to differ from GEBCO 2020 grid since most of EMODnet data in the area is based on GEBCO 2014 grid. This indicates one can expect noticeable differences not only between different bathymetry models but also between different versions of grids.

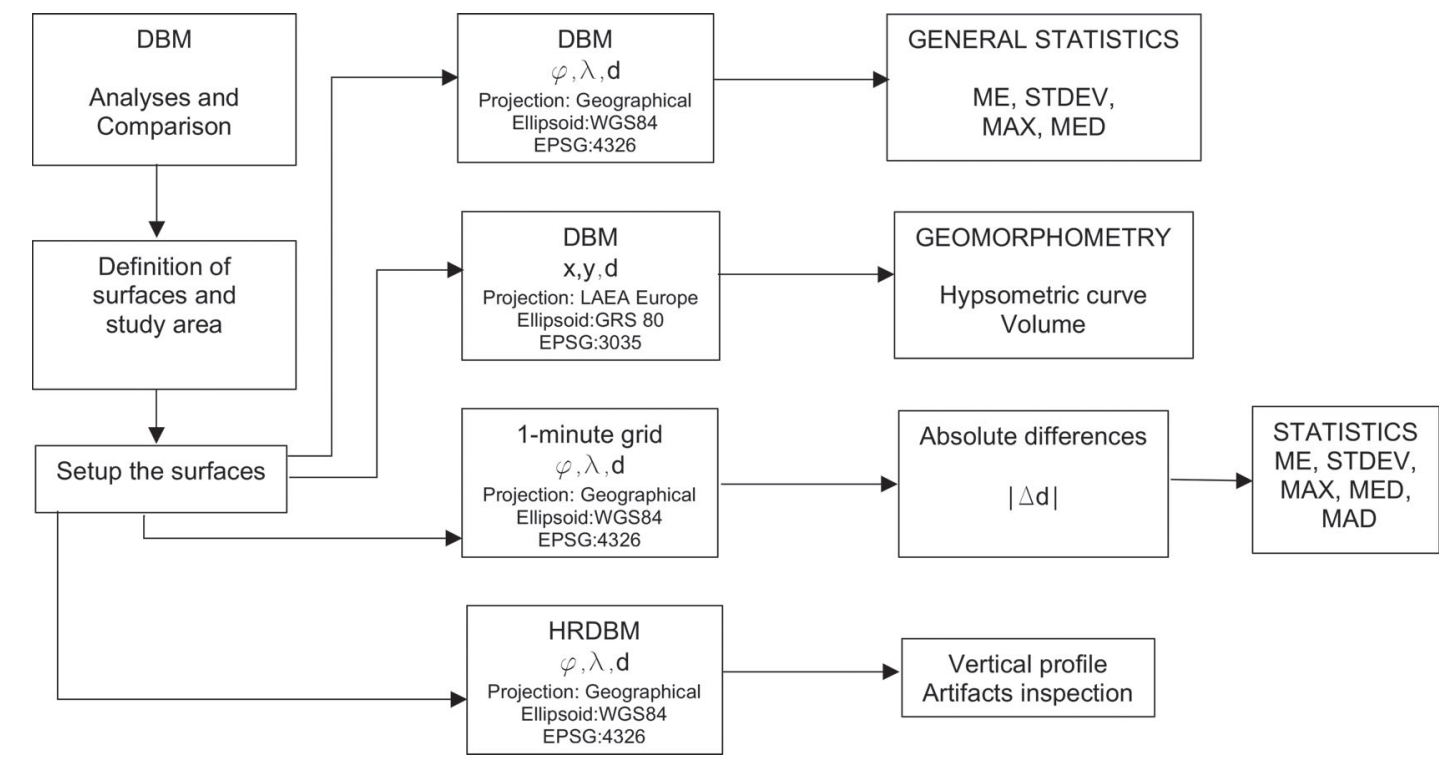

*DBM Digital bathymetry model, HRDBM High-resolution digital bathymetry model, ME Mean, STDEV Standard deviation, MAX Maximum, MED Median, MAD Mean absolute deviation

Figure 3 Flowchart overview of the analyse of digital bathymetry models $[5,16,43]$ Slika 3. Dijagram tijeka analize digitalnih batimetrijskih modela [5, 16, 43] 
Table 2 General statistics of digital bathymetry grids in continental shelf of Croatia [12,17, 18, 21, 23, 24]

Tablica 2. Osnovni statistički pokazatelji batimetrijskih modela u hrvatskom epikontinentalnom pojasu [12, 17, 18, 21, 23, 24]

\begin{tabular}{|c|c|c|c|c|}
\hline \multirow{2}{*}{ DBM } & \multicolumn{4}{|c|}{ Depth [m] } \\
\hline DTU & ME & St. Dev. & MED & MAX \\
\hline EMODNET & 226 & 330 & 107 & 1277 \\
\hline ETOPO & 216 & 322 & 96 & 1265 \\
\hline GEBCO & 221 & 303 & 100 & 1181 \\
\hline SRTM15+ & 219 & 326 & 98 & 1244 \\
\hline SS & 220 & 325 & 96 & 1241 \\
\hline
\end{tabular}

\subsection{Geomorphometry / Geomorfometrija}

In order to represent distribution of depth relative to the area they are covering, common geomorphometry function hypsometric curve was derived for all grids with the area calculated for 10-meter depth intervals (Figure 4). Greatest differences between models are observed in shallow areas with a depth of up to 250 meters which cover more than $85 \%$ of continental shelf of Croatia (Figure 5) and in the area of South Adriatic Pit (SAP), deeper than 1200 meters. DTU and ETOPO models show high peak in depth range from $0 \mathrm{~m}$ to $25 \mathrm{~m}$ and cover much more area in this depth range than other models but there is a loss of area in range from 25 meters to 100 meters as compared to others. This can be explained by their source data. DTU is based on GEBCO 1- minute grid which has a depth deficit in coastal area that is represented with depth of only 5 meters (Figure 2a). ETOPO is based on Smith and Sandwell (SS) grid in test area, but ETOPO was generated in 2008 and SS grid incorporated bathymetry data for Mediterranean area in 2013. In depth range of up to 250 meters, hypsometric curves are not smooth but have peeks. Peeks are detected in curves of all models at different depth values, i.e. regarding DTU model peeks are observed at $10 \mathrm{~m}, 50 \mathrm{~m}, 90 \mathrm{~m}, 130 \mathrm{~m}$ and for SS at $50 \mathrm{~m}$ and $70 \mathrm{~m}$, etc. Marks and Smith [33] noticed that a bias towards gridded digitized depth or contours in source data or flat sediment area could be seen as spikes in the hypsometric curve. As test area is not flat, but highly irregular due to well-indented coast, spikes are caused by source data. In depth range from $250 \mathrm{~m}$ to $1200 \mathrm{~m}$ hypsometric curves are uniform. Observable change happens in deepest area between $1200 \mathrm{~m}$ and $1250 \mathrm{~m}$ for SRTM15 and SS models. Although base layer for GEBCO 2020 is SRTM15+ model, in deepest part of continental shelf which covers part of South Adriatic Pit, GEBCO is augmented with EMODnet data based on multibeam survey.

\subsection{Absolute differences between models / Apsolutne razlike između modela}

Grids were resampled to same grid spacing of 1-minute using bilinear interpolation for pixel to pixel comparison. Absolute differences between grids were calculated in all combinations (Table 3). Absolute differences were classified in three depth intervals to get better representation of relative coherence. It should be noted that differences between models are calculated in shallow test area with 85 percent of depth under 250 meters (Figure 5).

DTU and ETOPO show the highest value of absolute differences in combination with all other models. Difference between DTU and ETOPO is presented in Figure 6a with biggest discrepancies in South Adriatic Pit as a result of different source

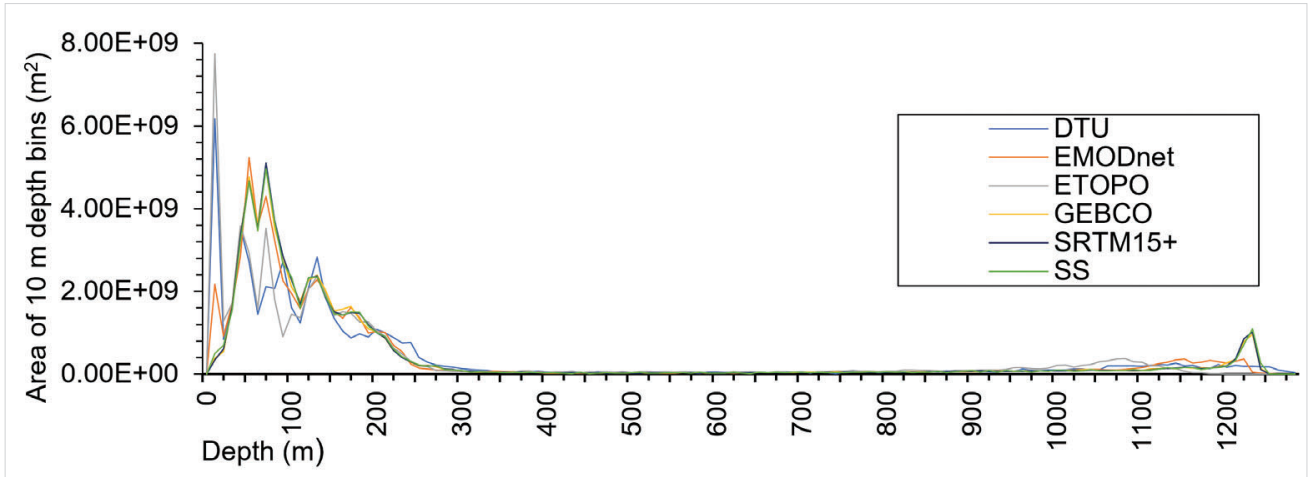

Figure 4 Hypsometry of the continental shelf of Croatia expressed as area for 10 m depth intervals $[12,17,18,21,23,24]$ Slika 4. Hipsometrijska krivulja u intervalima dubine od 10 metara na području hrvatskog epikontinentalnog pojasa [12, 17, 18, 21, 23, 24]

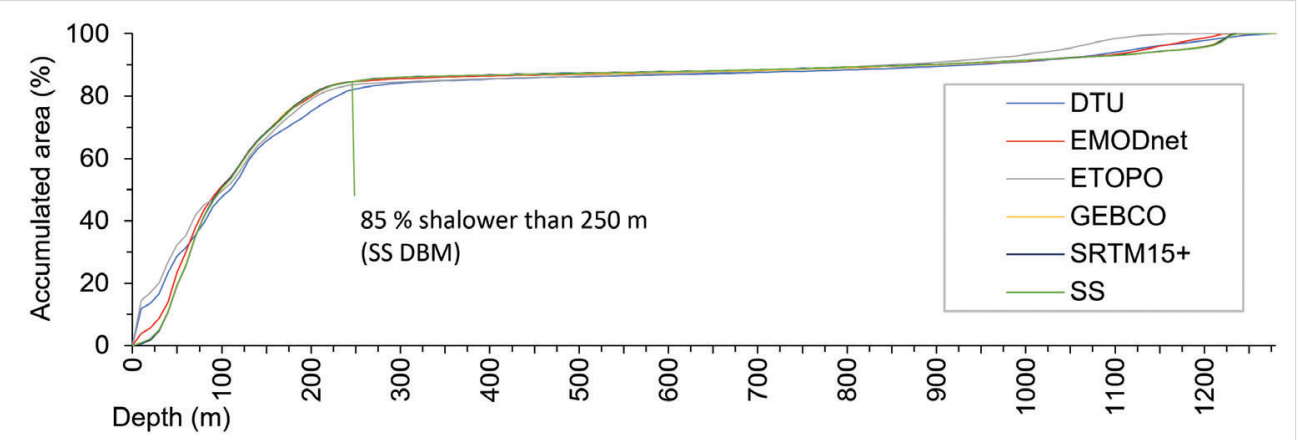

Figure 5 Hypsometry of continental shelf of Croatia expressed accumulated area in percent $[12,17,18,21,23,24]$ Slika 5. Hipsometrijska krivulja s površinom izaženom u postocima u odnosu na cijelo područje hrvatskog epikontinentalnog pojasa $[12,17,18,21,23,24]$ 
Table 3 Absolute differences between grids

Tablica 3. Absolutna vrijednost razlika između modela

\begin{tabular}{|c|c|c|c|c|c|c|c|c|c|}
\hline \multirow{3}{*}{ MODEL A } & \multirow{3}{*}{ MODEL B } & \multicolumn{8}{|c|}{$\left|\mathrm{DD}_{\text {model A-model B }}\right|$} \\
\hline & & MEDIAN & MAD & MEAN & STDEV & MAX & $|\mathrm{DD}|<25 \mathrm{~m}$ & $25 \mathrm{~m}<|\mathrm{DD}|<100 \mathrm{~m}$ & $|\mathrm{DD}|>100 \mathrm{~m}$ \\
\hline & & \multicolumn{5}{|c|}{$[\mathrm{m}]$} & \multicolumn{3}{|c|}{ [\%] } \\
\hline SRTM15+ & DTU & 15 & 13 & 31 & 37 & 251 & 61 & 33 & 6 \\
\hline DTU & SS & 15 & 13 & 30 & 35 & 236 & 61 & 33 & 5 \\
\hline DTU & EMODNET & 14 & 12 & 26 & 30 & 200 & 63 & 34 & 3 \\
\hline SRTM15+ & ETOPO & 12 & 11 & 34 & 48 & 381 & 64 & 28 & 8 \\
\hline DTU & GEBCO & 12 & 11 & 29 & 36 & 261 & 63 & 31 & 6 \\
\hline ETOPO & SS & 11 & 10 & 34 & 49 & 395 & 65 & 27 & 8 \\
\hline ETOPO & GEBCO & 10 & 9 & 32 & 48 & 387 & 67 & 24 & 9 \\
\hline DTU & ETOPO & 8 & 8 & 25 & 41 & 509 & 73 & 21 & 7 \\
\hline EMODnet & ETOPO & 8 & 7 & 26 & 40 & 404 & 70 & 24 & 5 \\
\hline SRTM15+ & EMODnet & 6 & 5 & 15 & 21 & 209 & 64 & 28 & 8 \\
\hline EMODnet & SS & 6 & 5 & 14 & 20 & 176 & 84 & 15 & 1 \\
\hline EMODnet & GEBCO & 4 & 3 & 11 & 19 & 176 & 88 & 11 & 1 \\
\hline GEBCO & SS & 3 & 2 & 6 & 9 & 133 & 97 & 3 & 0 \\
\hline SRTM15+ & GEBCO & 2 & 1 & 5 & 9 & 157 & 97 & 3 & 0 \\
\hline SRTM15+ & SS & 2 & 1 & 5 & 8 & 124 & 99 & 1 & 0 \\
\hline
\end{tabular}

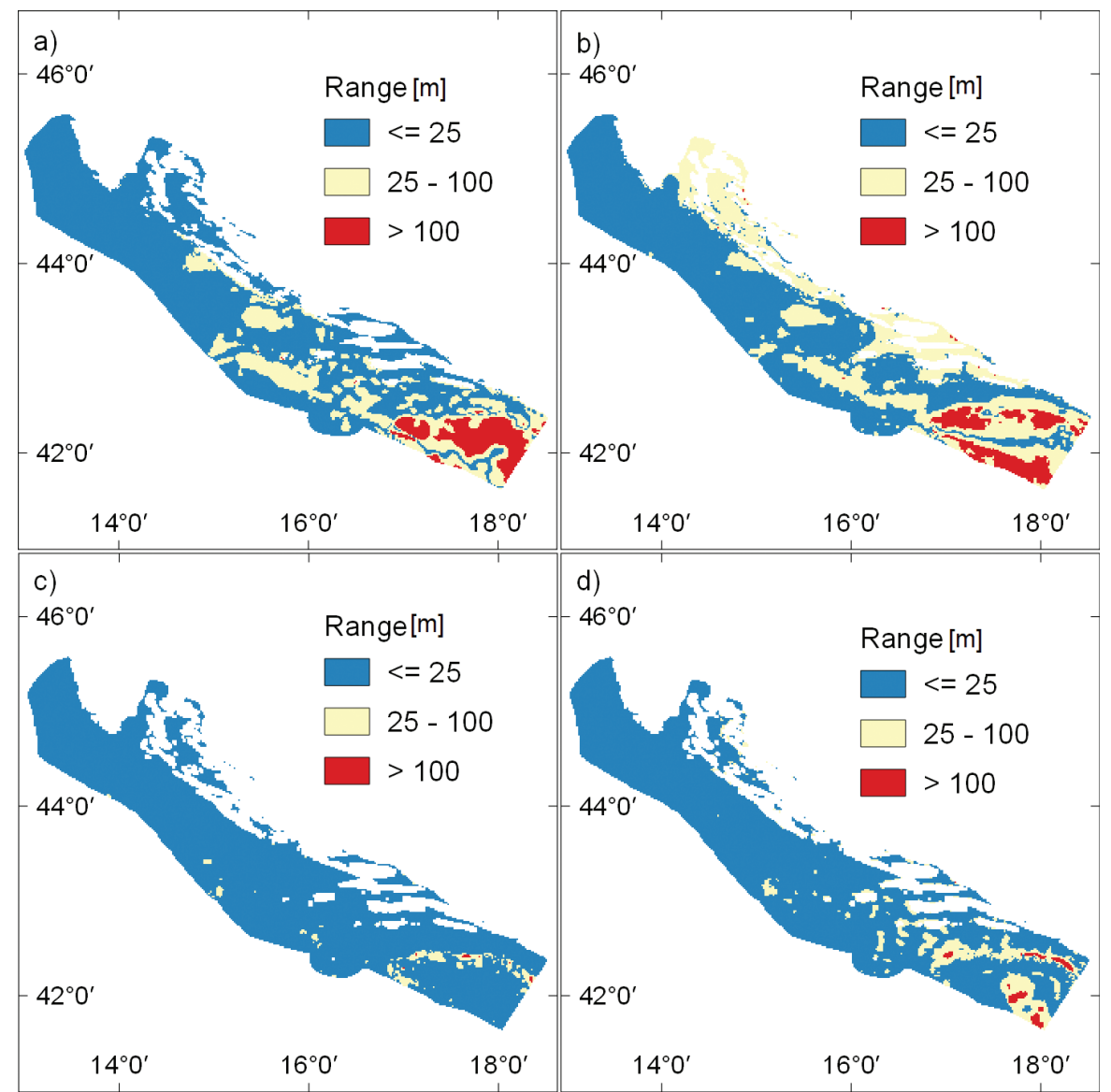

Figure 6.a) Absolute differences between DTU and ETOPO, b) Absolute differences between DTU and SRTM15+, c) Absolute differences between GEBCO and SRTM15+, d) Absolute differences between GEBCO and EMODnet

Slika 6.a) Apsolutne razlike između DTU i ETOPO, b) Apsolutne razlike između DTU i SRTM15+, c) Apsolutne razlike između GEBCO i SRTM15+, d) Apsolutne razlike između GEBCO i EMODnet

data and interpolation method. The greatest difference between models is between DTU and SRTM15+ with average value of $31 \mathrm{~m}$, standard deviation of $37 \mathrm{~m}$ and maximum of $251 \mathrm{~m}$. As seen from hypsometric curve (Figure 4) and distribution of absolute differences (Figure 6b), great inconsistency between models happens in coastal area. This is due to difference in source data but also to limitations of satellite altimetry near land area and consequently degradation of the accuracy of gravity predicted depths. GEBCO, SRTM15+ and Smith and Sandwell (SS) grid show best coherence with more than 95 percent of differences smaller than 25 meters. SRTM15+ and SS model have relatively best fit with mean difference of 5 meters, standard deviation of $8 \mathrm{~m}$ and 99 per cent of absolute differences 
smaller than $25 \mathrm{~m}$. SRTM15+ and SS grid share completely identical source data but small difference between them is due to the difference in interpolation and resolution. GEBCO, whose base layer is SRTM15+, shows slightly greater difference as compared to SRTM15+ and SS with 97 per cent of depth differences smaller than 25 but this can be explained with EMODnet data incorporated into grid (Figure 6c). As mentioned in section 3.1, EMODnet bathymetry model surprisingly shows difference between GEBCO model with maximum absolute difference of $176 \mathrm{~m}$ (Figure $6 \mathrm{~d}$ ). In test area EMODnet grid is mostly based on GEBCO 2014, and GEBCO 2020 has merged EMODnet direct soundings into his grid. However, base layer of GEBCO 2014 is GEBCO08 (SRTM30+V.5) and of GEBCO 2020 is SRTM15+V2.1. Discrepancy between models is due to different version of base layer.

Bjelotomić [5] in 2015 mutually compared digital bathymetry models in the Adriatic Sea for a specific task in physical geodesy, computing a geoid. Among others DTU10BAT, ETOPO 1, GEBCO 2014, Smith and Sandwell Version18.1 and SRTM 30+. Although results cannot be directly compared due to difference in test area and version of models, some correlation can be made. Same differences between DTU10BAT and ETOPO observed in Figure 6a can be seen in Bjelotomić. Smith and Sandwell and SRTM+ model always show great compatibility due to the same source data. GEBCO 2014 had great shortcoming in shallow coastal area as compared to other models in Bjelotomić, but for GEBCO 2020 this is not the case and it shows great improvement in most recent version. As discussed in earlier studies [20, 21, 24], differences between models are caused by several factors: density and distribution of underlying source data, interpolation method used for grid construction and resolution of grid.

\subsection{Comparison with high resolution digital bathymetry model (HRDBM) / Usporedba s digitalnim modelom visoke rezolucije}

Bathymetry grids were compared with high resolution digital bathymetry model HRDBM with $2 \mathrm{~m}$ grid spacing calculated from multibeam data in the area of Murter Sea (Figure 7a). Area of Murter Sea is coastal shallow area with well indented coast and depths in range from $0 \mathrm{~m}$ to $180 \mathrm{~m}$. Vertical profile $A A^{\prime}$ was generated for all bathymetry grids.
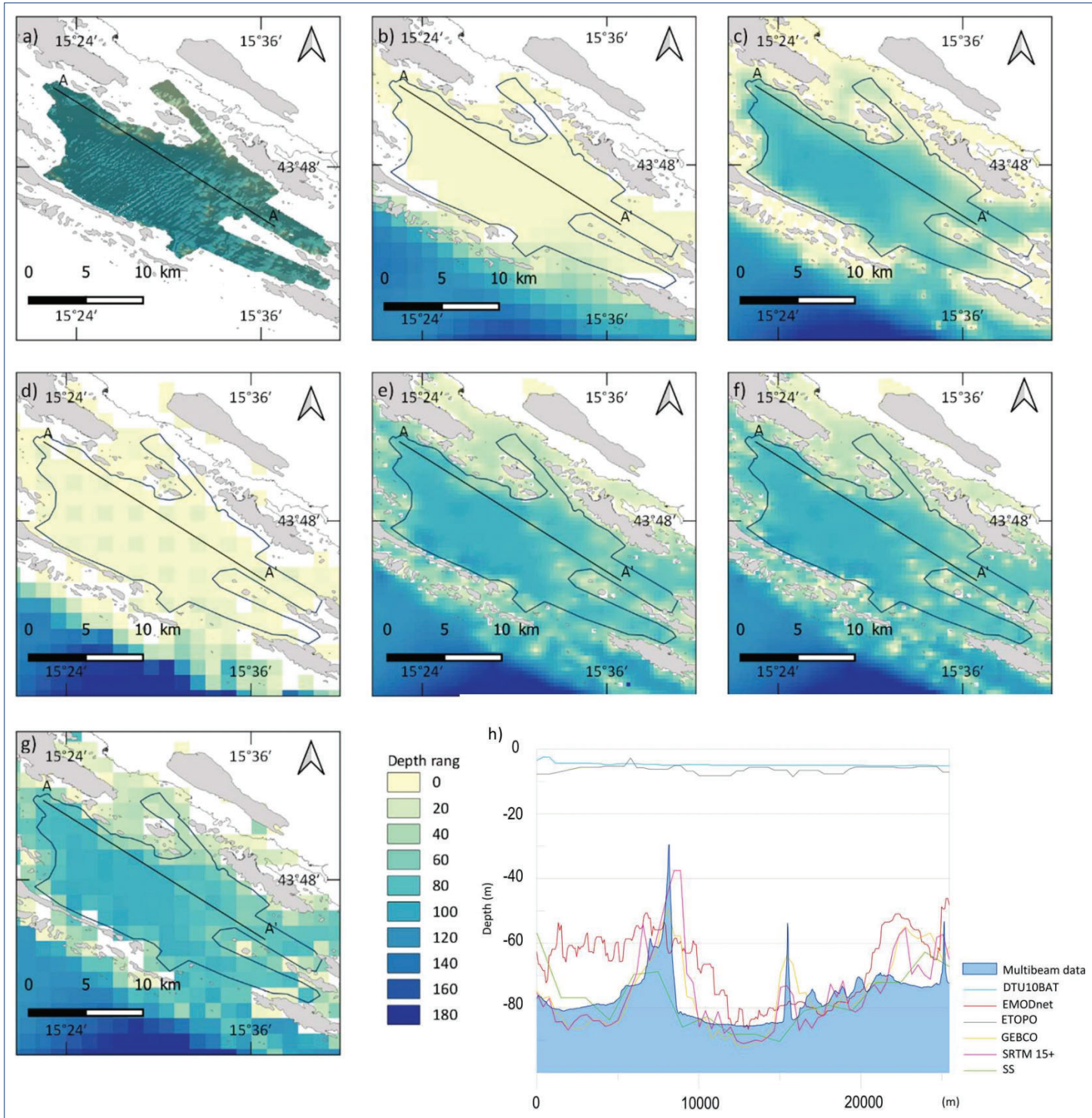

Figure 7 Bathymetry of Murter Sea: a) High resolution digital bathymetry model HRDBM, b) DTU, c) EMODnet, d) ETOPO, e) GEBCO, f) SRTM15+, g) Smith and Sandwell h) vertical profiles AA' derived from all bathymetry grids

Slika 7. Batimetrijski modeli na području Murterskog mora: a) Batimetrijski model visoke rezolucije HRDBM, b) DTU, c) EMODnet, d) ETOPO, e) GEBCO, f) SRTM5+, g) Smith i Sandwell, h) vertikalni profil AA' iscrtan za svaki model 


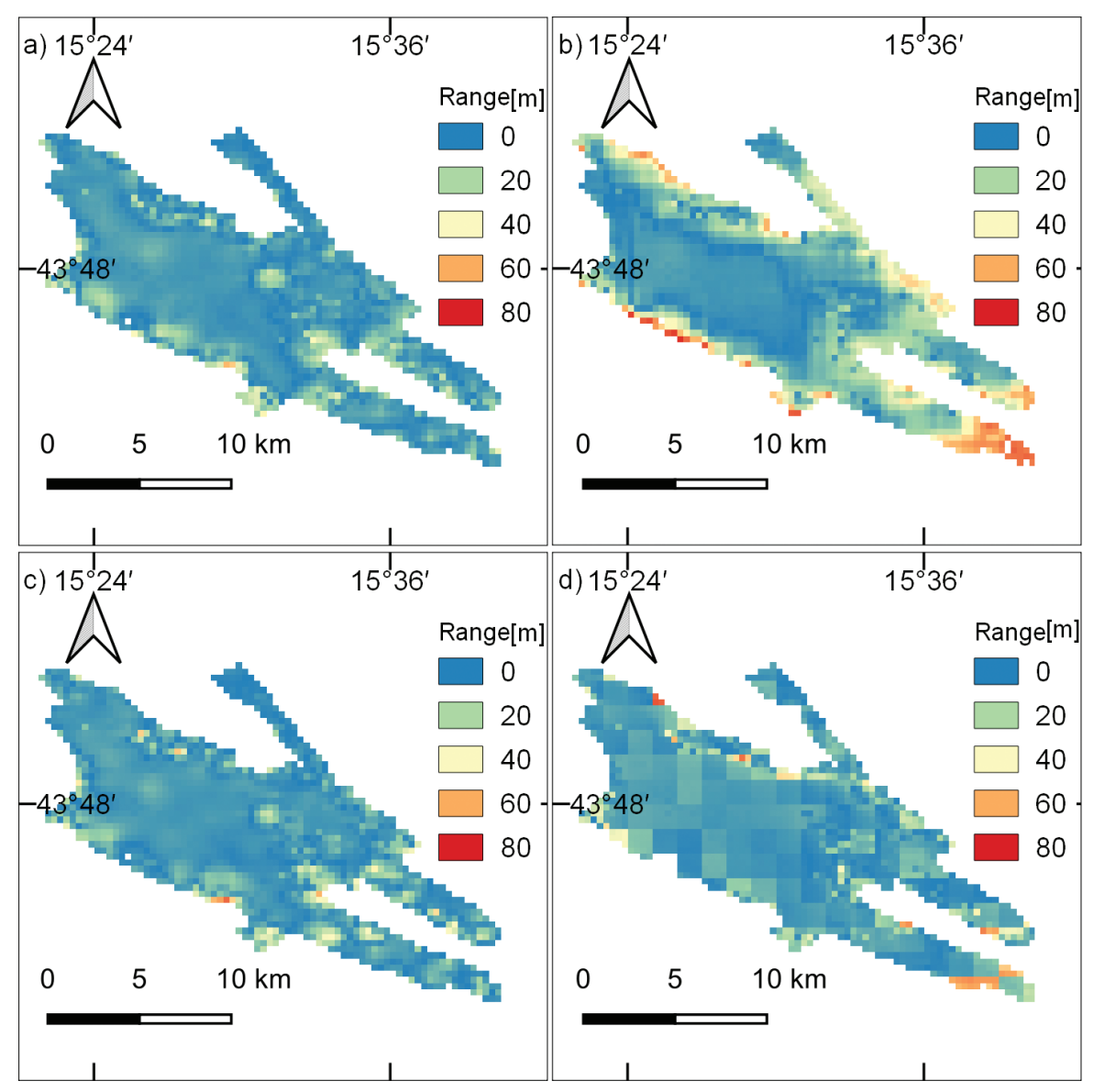

Figure 8 Absolute difference between HRDBM and publicly available grids: a) GEBCO, b) EMODnet, c) SRTM15+, d) Smith and Sandwell Figure 8. Apsolutne razlike između podataka izmjere višesnopnim dubinomjerom i javno dostupnih modela: a) GEBCO, b) EMODnet, c) SRTM15+, d) Smith i Sandwell

Difference in resolution is the first thing to be noticed by visual inspection of digital grids. ETOPO, DTU and Smith and Sandwell (SS) have coarser resolution as compared to other grids and that is evident by visual interpretation. Furthermore, DTU and ETOPO show great deficiency of depth in the area as seen in Figure $7 \mathrm{~b}$ and $7 \mathrm{~d}$. Both models have a constant depth of about 5 $m$ as can be seen in their vertical profiles (Figure 7h). They do not represent the seafloor terrain and are inaccurate for the area. As for other models, they all have artifacts but represent sea floor far better than DTU and ETOPO (Figure 8a - 8d).

Compatibility between GEBCO, SRTM15+ and SS is evident from their vertical profiles (Figure 7h). As compared to multibeam data it can be noticed that SS has the worst alignment of those three grids and cannot depict small shoals and reefs as GEBCO and SRTM15, but this is probably due to his coarser resolution. It was expected from EMODnet to show the best fit because it is the grid with highest resolution that should be based on survey data from authoritative sources. Unfortunately, in the area it is based mostly on GEBCO2014 data that is inferior to GEBCO2020 when compared to multibeam data. EMODnet seems much smoother than GEBCO and SRTM15+ and does not depict small reefs and shoals as well as they do, due to source data and interpolation method.

\section{CONCLUSION / Zaključak}

Analyses and mutual comparison between six publicly available grids in the area of Croatian continental shelf reveals that for marine researchers GEBCO2020 digital bathymetry model would, at the present moment, be the best choice. Although EMODnet grid has four times higher resolution of 3.75 " and is based on surveys from authoritative sources, gaps between these data are filled with GEBCO 2014 grid. Unfortunately, in the test area, there are huge gaps covering most of the area and GEBCO2014 (base layer SRTM30+) bathymetry showed shortcoming of depth in shallow areas near coast. GEBCO2020 is superior to EMODnet digital bathymetry model (DBM) for two reasons, it is the latest, updated version of GEBCO grid based on SRTM15+ model and it is augmented with direct soundings from EMODnet grid in the test area. The fact that surveys from EMODnet data are part of GEBCO grid, especially in the deepest area of South Adriatic Pit makes GEBCO grid more reliable than its base layer SRTM 15+. Smith and Sandwell (SS) one-minute grid differs from SRTM15+ digital bathymetry model with 15 seconds grid spacing, only in resolution because they are based on the same source data. DTU and ETOPO grid show great depth deficiency in shallow coastal area and have the smallest alignment with other models. As digital bathymetry models, especially SS, SRTM+ and EMODnet are regularly updated with new data there are significant differences between different versions of models and the latest one should be used. Differences between models are due to density and distribution of underlying source data, interpolation method used for grid construction and resolution of grid. For that reason, describing source data is a key element for users of bathymetry data to understand the context in which the data has been acquired, how it has been processed, and its expected quality. Most 
of publicly available bathymetry grids rarely have quality indicators as their quality is expressed with statistical value of adequacy (tipically Root Mean Square Error) between them and reference data on global level or simply indicate the origin of soundings by accompanied grids. EMODnet is the only grid offering a detailed description of its quality at the geographical level, providing information about survey method, data quality and link to the data holder through metadata. Regarding the fact that it is almost impossible to obtain information about the quality of source data at present stage, for a quality assessment of publicly available grids and statistically determining which grid is the best fit in particular marine region, grids should be compared with reliable soundings from nautical charts or survey data.

\section{Aknowledgment / Zahvale}

Special thanks to Hydrographic Institute of the Republic of Croatia for the permission to use bathymetry data of Murter Sea for scientific and research purposes.

\section{REFERENCE / Literatura}

[1] Abramova, A. S. (2012). Comparison and Evaluation of Global Publicly Available Bathymetry Grids in the Arctic. MSc Thesis, Durham, Faculty of New Hempshire.

[2] Amante, C., Eakins, B. W. (2009). ETOPO1 1 Arc-Minute Global Relief Model: Procedures, Data Sources and Analysis, NOAA Technical Memorandum NESDIS NGDC-24.

[3] Andersen, O. B., Knudsen, P. (2008). The DTU10 global Mean sea surface and Bathymetry, European Geosciences Union General Assembly 2008.

[4] Bašić, T., Buble, G. (2007). “Usporedba globalnog modela visina SRTM3 s postojećim digitalnim modelima reljefa na području Hrvatske". Geodetski list, Vol. 61, No. 84 (2), pp. 93-111.

[5] Bjelotomić, O. (2015). High Resolution Geoid Modelling of Croatia. PhDThesis. Zagreb, Faculty of Geodesy of University of Zagreb.

[6] British Oceanographic Data Centre. (2003). Centenary Edition of the GEBCO Digital Atlas [CD-ROM], Intergovernmental Oceanographic Commission and the International Hydrographic Organization, Liverpool, UK.

[7] Calvert, J., Strong, J. A., Service, M., McGonigle, C., Quinn, R. (2015). “An evaluation of supervised and unsupervised classification techniques for marine benthic habitat mapping using multibeam echosounder dana". ICES Journal of Marine Science, Vol. 72, No. 5, pp. 1498-1513. https://doi. org/10.1093/icesjms/fsu223

[8] Chiocci, F. L., Cattaneo, A., Urgeles, R. (2011). “Seafloor mapping for geohazard assessment: State of the art". Marine Geophysical Research, Vol. 32, No. 1, pp. 1-11. https://doi.org/10.1007/s11001-011-9139-8

[9] Eakins, B. W., Sharman, G. F. (2010). Volumes of the World's Oceans from ETOPO1, NOAA National Geophysical Data Center, Boulder, CO.

[10] EMODnet Bathymetry Consortium. (2018). EMODnet Digital Bathymetry (DTM 2018). DOI: 10.12770/18ff0d48-b203-4a65-94a9-5fd8b0ec35f6.

[11] Florentino, C., Vitor, P., Neto, A. A. (2019). "Methodology for quality analysis of regional batymetry surfaces: From Brazilian South Coast to Hunter Channel". International Hydrographic Review, No. November 2019.

[12] ftp://topex.ucsd.edu/pub/global_topo_1 $1 \mathrm{~min} /$ [accessed 1/9/2020]

[13] GEBCO Bathymetric Compilation Group (2019). GEBCO 2019 Grid. DOI: 10.5285/836f016a-33be-6ddc-e053-6c86abc0788e.

[14] GEBCO Bathymetric Compilation Group. (2020). GEBCO 2020 Grid. DOI: 10.5285/a29c5465-b138-234d-e053-6c86abc040b9.

[15] Gille, S. T., Joseph Metzger, E., Tokmakian, R. (2004). "Seafloor topography and ocean circulation". Oceanography, Vol. 17, No. 1 (Special Issue), pp. 47-54. https://doi.org/10.5670/oceanog.2004.66

[16] Höhle, J., Höhle, M. (2009). "Accuracy assessment of digital elevation models by means of robust statistical methods". ISPRS Journal of Photogrammetry and Remote Sensing, Vol. 64, No. 4, pp. 398-406. https://doi.org/10.1016/j. isprsjprs.2009.02.003

[17] https://download.gebco.net/ [accessed 1/9/2020]

[18] https://portal.emodnet-bathymetry.eu/\# [accessed 15/8/2020]

[19] https://seabed2030.gebco.net/faq/ [accessed 9/9/2020]

[20] https://topex.ucsd.edu/cgi-bin/get_data.cgi [accessed 1/9/2020]

[21] https://topex.ucsd.edu/WWW_html/srtm15_plus.html [accessed 1/9/2020]

[22] ttps://www.gebco.net/data_and_products/historical_data_sets/\#gebco_ one [accessed 1/9/2020]

[23] https://www.ngdc.noaa.gov/mgg/global/global.html [accessed 20/8/2020]

[24] https://www.space.dtu.dk/english/research/scientific_data_and_models/ global_bathymetry_model [accessed 1/9/2020]
[25] INSPIRE Thematic Working Group Coordinate Reference Systems \& Geographical Grid Systems (2014). INSPIRE D2.8.I.2 Data Specification on Geographical Grid Systems - Technical Guidelines, INSPIRE Data Specification, No. March.

[26] International Hydrographic Organisation (2008). IHO Standards fo Hydrographic Surveys S-44, International Hydrographic Bureu, Monaco.

[27] International Maritime Organization (1974). International Convention for the Safety of Life At Sea - SOLAS, London, UK.

[28] Jakobsson, M., Stranne, C., O'Regan, M., Greenwood, S. L., Gustafsson, B., Humborg, C., Weidner, E. (2019). "Bathymetric properties of the Baltic Sea". Ocean Science, Vol. 15, No. 4, pp. 905-924. https://doi.org/10.5194/os-15-905-2019

[29] Jašić, D., Bićanić, Z., Kasum, J. (2002). "The Central Adriatic Shelf - Important Research and Data Processing Methodology". Geoadria, Vol. 7, No. 1, pp. 127-143.

[30] Kulikov, E. A., Gusiakov, V. K., Ivanova, A. A., Baranov, B. V. (2016). "Numerical tsunami modeling and the bottom relief". Moscow University Physics Bulletin, Vol. 71, No. 6, pp. 527-536. https://doi.org/10.3103/S002713491605012X

[31] Lecours, V., Dolan, M. F. J., Micallef, A., Lucieer, V. L. (2016). “A review of marine geomorphometry, the quantitative study of the seafloor". Hydrology and Earth System Sciences, Vol. 20, No. 8, pp. 3207-3244. https://doi.org/10.5194/ hess-20-3207-2016

[32] Li, Z., Zhu, C., Gold, C. (2004). Digital Terrain Modeling Principles and Methodology. London: CRC Press. https://doi.org/10.1201/9780203357132

[33] Marks, K. M., Smith, W. H. F. (2006). "An evaluation of publicly available global bathymetry grids". Marine Geophysical Research, Vol. 27, No. 1, pp. 19-34. https://doi.org/10.1007/s11001-005-2095-4

[34] Mayer, L., Jakobsson, M., Allen, G., Dorschel, B., Falconer, R., Ferrini, V., Lamarche, G., Snaith, H., Weatherall, P. (2018). "The Nippon Foundation GEBCO Seabed 2030 Project:The Quest to See the World's Oceans Completely Mapped by 2030". Geosciences, Vol. 8, No. 2, pp. 1-18. https://doi.org/10.3390/ geosciences 8020063

[35] Russo, A., Artegiani, A. (1996). “Adriatic Sea hydrography”. Scientia Marina, Vol. 60, No. 2, pp. 33-43.

[36] Sandwell, D. T., Müller, R. D., Smith, W. H. F., Garcia, E., Francis, R. (2014) "New global marine gravity model from CryoSat-2 and Jason-1 reveals buried tectonic structure". Science, Vol. 346, No. 6205, pp. 65-67. https://doi. org/10.1126/science.1258213

[37] Smith, W. H. F., Sandwell, D. T. (1994). "Bathymetric prediction from dense satellite altimetry and sparse shipboard bathymetry". Journal of Geophysical Research: Solid Earth, Vol. 99, No. B11, pp. 21803-21824. https://doi org/10.1029/94JB00988

[38] Smith, W. H. F., Sandwell, D. T. (1997). "Global Sea Floor Topography from Satellite Altimetry and Ship Depth Soundings". Science, Vol. 277, No. 5334, pp 1956-1962. https://doi.org/10.1126/science.277.5334.1956

[39] Šepić, J., Međugorac, I., Janeković, I., Dunić, N., Vilibić, I. (2016). "MultiMeteotsunami Event in the Adriatic Sea Generated by Atmospheric Disturbances of 25-26 June 2014". Pure and Applied Geophysics, Vol. 173, No. 12, pp. 4117-4138. https://doi.org/10.1007/s00024-016-1249-4

[40] Thierry, S., Dick, S., George, S., Benoit, L., Cyrille, P. (2019).“EMODnet Bathymetry a Compilation of Bathymetric Data in the European Waters". OCEANS 2019 Marseille, IEEE, pp. 1-7. https://doi.org/10.1109/OCEANSE.2019.8867250

[41] Tozer, B., Sandwell, D. T., Smith, W. H. F., Olson, C., Beale, J. R., Wessel, P. (2019). "Global Bathymetry and Topography at 15 Arc Sec: SRTM15+". Earth and Space Science, Vol. 6, No. 10, pp. 1847-1864. https://doi.org/10.1029/2019EA000658

[42] United Nations (1982). United Nations Convention on the Law of the Sea UNCLOS, Montego Bay, Jamaica.

[43] Varga, M., Bašić, T. (2013). "Quality assessment and comparison of global digital elevation models for Croatia". Kartografija i geoinformacije, Vol. 12, No. 20, pp. 4-17.

[44] Varga, M., Grgić, M., Oršulić, O. B., Bašić, T. (2019). “Influence of digital elevation model resolution on gravimetric terrain correction over a study-area of Croatia". Geofizika, Vol. 36, No. 1, pp. 17-32. https://doi.org/10.15233/gfz.2019.36.1

[45] Vilibić, I., Domijan, N., Orlić, M., Leder, N., Pasarić, M. (2004). "Resonant coupling of a traveling air pressure disturbance with the east Adriatic coastal waters". Journal of Geophysical Research: Oceans, Vol. 109, No. 10, pp. 1-13. https://doi.org/10.1029/2004JC002279

[46] Viličić, D. (2014). "Specifična oceanološka svojstva hrvatskog dijela Jadrana". Hrvatske vode, Vol. 22, No. 90, pp. 297-314

[47] Vokić Žužul, M., Filipović, V. (2015). “Granice podmorskih prostora jadranskih država". Poredbeno pomorsko pravo, Vol. 54, No. 169, pp. 9-56.

[48] Weatherall, P., Marks, K. M., Jakobsson, M., Schmitt, T., Tani, S., Arndt, J. E., Rovere, M., Chayes, D., Ferrini, V., Wigley, R. (2015). “A new digital bathymetric model of the world's oceans". Earth and Space Science, Vol. 2, No. 8, pp. 331 345. https://doi.org/10.1002/2015EA000107

[49] Wilson, M. F. J., O'Connell, B., Brown, C., Guinan, J. C., Grehan, A. J. (2007). "Multiscale Terrain Analysis of Multibeam Bathymetry Data for Habitat Mapping on the Continental Slope". Marine Geodesy, Vol. 30, No. 1-2, pp. 3-35. https://doi.org/10.1080/01490410701295962

[50] Wölfl, A. C., Snaith, H., Amirebrahimi, S., Devey, C. W., Dorschel, B., Ferrini, V., Huvenne, V. A. I., Jakobsson, M., Jencks, J., Johnston, G., Lamarche, G Mayer, L., Millar, D., Pedersen, T. H., Picard, K., Reitz, A., Schmitt, T., Visbeck, M., Weatherall, P., Wigley, R. (2019). "Seafloor mapping - The challenge of a truly global ocean bathymetry". Frontiers in Marine Science, No. 6. https://doi. org/10.3389/fmars.2019.00283 